\title{
LIDAR OBSERVATIONS OF POLLUTION TRANSPORT FROM LONDON TO RURAL AREAS
}

\author{
Hugo Ricketts ${ }^{1,2 *}$, Geraint Vaughan ${ }^{1,2}$, David Wareing ${ }^{3}$ \\ ${ }^{1}$ School of Earth, Atmospheric and Environmental Sciences, University of Manchester, United Kingdom \\ *Email: h.ricketts@manchester.ac.uk \\ ${ }^{2}$ National Centre for Atmospheric Science, United Kingdom \\ ${ }^{3}$ Institute of Mathematics, Physics and Computer Science, Aberystwyth University, United Kingdom
}

\begin{abstract}
The Clean Air for London (ClearfLo) Project took place in and around London, United Kingdom. The aim of the project was to learn how both atmospheric dynamics and chemistry affect air pollution in the south east of England. During the winter and summer of 2012 many different types of instrument including lidars were deployed throughout London city centre, suburbs and into rural areas. Amongst these instruments was the Boundary Layer Aerosol/Ozone Lidar owned by the National Centre for Atmospheric Sciences (NCAS) in the United Kingdom. Ozone and aerosol data are presented from data collected during July and August 2012 and compared to back trajectories to identify their origins.
\end{abstract}

\section{INTRODUCTION}

During the winter and summer of 2012 a field experiment called Clean air for London (ClearfLo) was carried out in the south east of England [1]. The aim of the project was to observe the dynamics and chemistry and analyse how these impact on air pollution in the Greater London area as well as further afield at more rural sites. A large amount of data was collected using many different scientific instruments including the United Kingdom's National Centre for Atmospheric Science's (NCAS) Boundary Layer Aerosol/Ozone Lidar System. This paper will discuss some of the results.

\section{CLEARFLO PROJECT}

As well as field sites in the Greater London area, the ClearfLo project included rural field sites to the East and West of London. During the winter and summer of 2012 two intensive observation periods (IOPs) were carried out to analyse different seasons and their effect on the chemistry

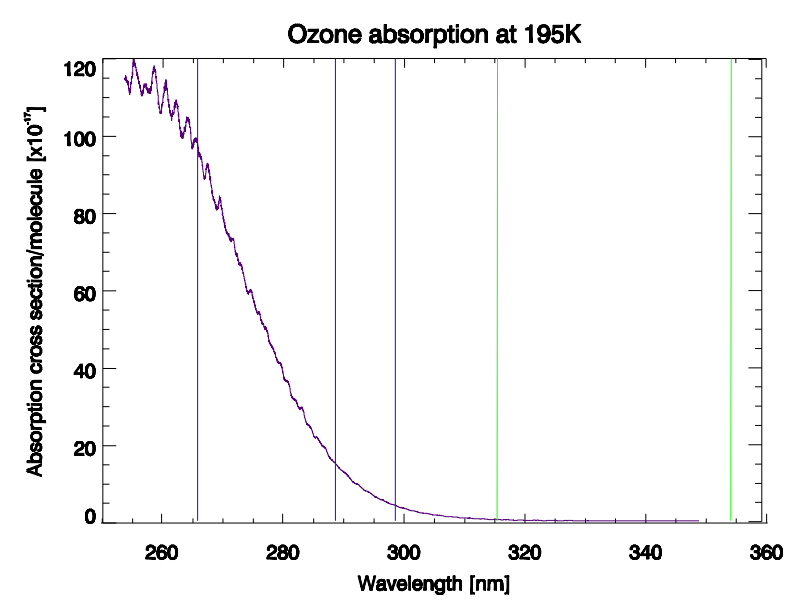

Fig. 1: Absorption cross-section of ozone at 195K [3]

and dynamics. During these IOPs, the NCAS Boundary Layer Aerosol/Ozone Lidar System was deployed to the Rutherford Appleton Laboratories (RAL) at Harwell Campus $80 \mathrm{~km}$ west of London's City Centre as part of the field experiment. Its purpose was to detect ozone concentrations and aerosol backscatter for the atmospheric boundary layer (ABL) and lower free troposphere (FT) to provide estimates of ozone flux towards or away from London depending on wind direction. While the lidar did not produce any data in the winter IOP, it proved to be a useful tool for analyzing data from the summer IOP.

During July and August 2012 the lidar was operational most days, except during rainy periods. The synoptic situation of summer 2012 presented plenty of variety; frontal systems passing over the UK from the Atlantic Ocean generally leading to westerly winds and also some high pressure situations leading to more variable wind directions including Easterlies. Only data with wind blowing from easterly directions will be presented here as this air was advected from London over Harwell Campus. Specifically, this 


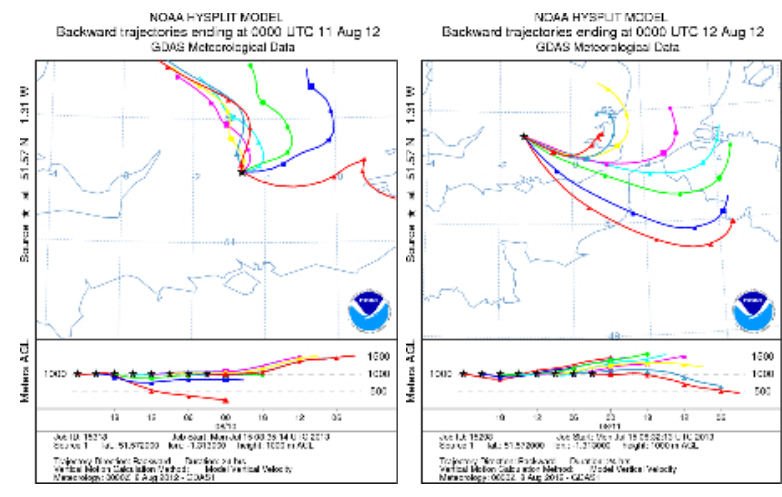

Fig. 2: Back trajectories from the HYSPLIT Model tracing the origin of the air mass seen by the lidar at $1 \mathrm{~km}[2]$.

study will focus on the time period of $10^{\text {th }}$ and $11^{\text {th }}$ August.

\section{NCAS AEROSOL/OZONE LIDAR}

\subsection{Description}

The NCAS Boundary Layer Aerosol/Ozone Lidar system is mounted on a small trailer allowing it to be transported to anywhere with road access. It was originally built by Elight Systems in 2002 and has since been operational at various locations in the United Kingdom (UK). The lidar system contains a Continuum Powerlite 8020 Nd:YAG laser with a pulse repetition frequency of $20 \mathrm{~Hz}$ capable of producing laser pulses of $355 \mathrm{~nm}$ and $266 \mathrm{~nm}$ through frequency-tripling and quadrupling of the original $1064 \mathrm{~nm}$ pulse, respectively. A further three wavelengths can then be produced using Stimulated Raman Scattering, whereby the $266 \mathrm{~nm}$ laser pulse is directed through

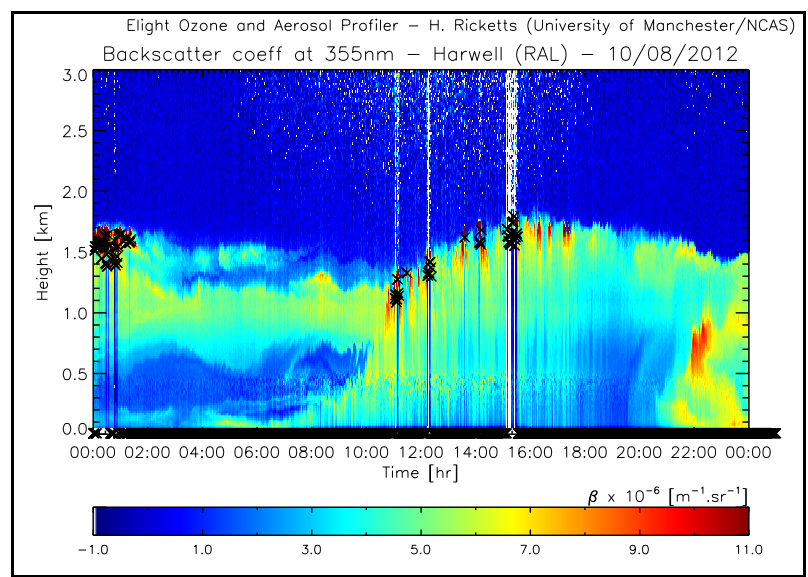

cells containing Hydrogen, Deuterium and Argon at different ratios. The wavelengths created by these cells are 289nm, 299nm and 316nm. Finally, each of the 5 wavelengths are sequentially transmitted vertically into the atmosphere allowing a complete set of measurements to be created at a rate of $4 \mathrm{~Hz}$.

The backscattered light is collected using a reflector telescope with a primary mirror diameter of $40 \mathrm{~cm}$ and the light is collected in two different focal planes to prevent saturation of the lidar detection system close to the telescope. To collect the backscattered light two Hamamatsu photomultiplier tubes (PMTs) are connected to an analogue to digital (A/D) converter designed by Licel $\mathrm{GmbH}$. The data is them stored at a range resolution of 7.5 metres and a time resolution of typically 3 minutes.

\subsection{Data analysis}

To obtain aerosol backscatter coefficient a simple onion-peeling algorithm after Klett [4] is used and therefore a Lidar Ratio (extinction-to-backscatter ratio) needs to be assumed. For the UK, typically a Lidar Ratio of $55 \mathrm{sr}$ can be taken for aerosol from a continental air mass and 30sr is used for marine air masses as measured from other UK lidar systems based at Capel Dewi near Aberystwyth, Wales [5]. The wavelengths analysed using this method are $355 \mathrm{~nm}$ and 316nm. Typically, aerosol backscatter coefficient can be obtained from $100 \mathrm{~m}$ up to $5-8 \mathrm{~km}$, depending on atmospheric condition.

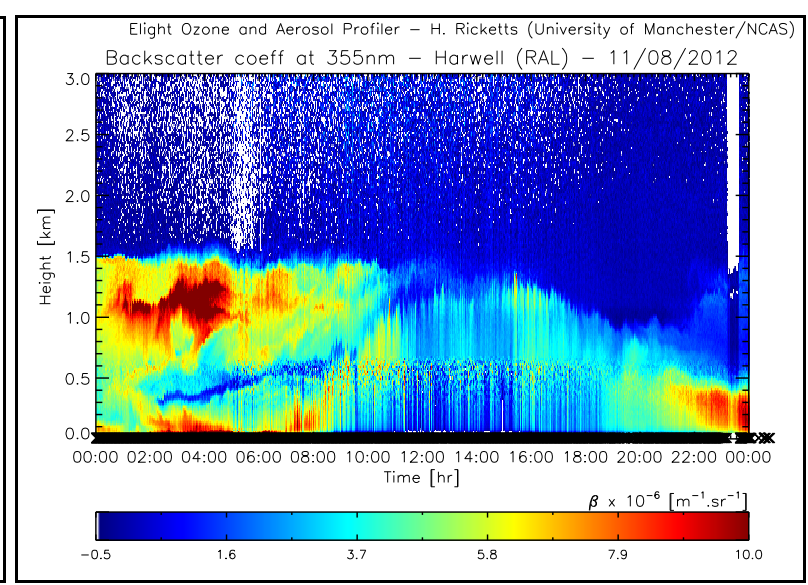

Fig. 3: Aerosol backscatter coefficient at $355 \mathrm{~nm}$ as measured by the lidar on $10^{\text {th }}$ and $11^{\text {th }}$ August 2012. 
To retrieve ozone mixing ratio a differential absorption lidar (DIAL) technique is used which calculates ozone mixing ratio from the slope in two of the backscatter signals. Firstly, this requires the removal of the backscatter due to aerosol and secondly, this leads to vertical averaging. The technique is also sensitive to the wavelength pairs used. Fig. 1 shows the absorption cross-section of ozone. While comparatively strong at $266 \mathrm{~nm}$, it decreases significantly with increasing wavelength. Therefore, in the presence of ozone, the $266 \mathrm{~nm}$ is absorbed more rapidly than the higher wavelengths of $289 \mathrm{~nm}$ and $299 \mathrm{~nm}$. This stronger absorption leads to a more reliable retrieval of ozone, but with reduced range. Therefore wavelength pairs $266 \mathrm{~nm} / 289 \mathrm{~nm}$ and $266 \mathrm{~nm} / 299 \mathrm{~nm}$ can be used up to about $2 \mathrm{~km}$ with an error of about $+/-2$ ppbv. Above that the less absorbed wavelength pair $289 \mathrm{~nm} / 299 \mathrm{~nm}$ can be used up to $2.5-3.5 \mathrm{~km}$ (depending on conditions) with an error of about $+/-5 \mathrm{ppbv}$, due to the much smaller difference between their respective absorption cross-sections.

\section{POLLUTION ADVECTION}

Fig. 2 shows back trajectory calculations calculated from the HYSPLIT Model [2]. This data shows where the air sampled by the lidar at 1 $\mathrm{km}$ is expected to have originated. During $10^{\text {th }}$ August 2012 the wind veers from a northerly to an easterly direction and on $11^{\text {th }}$ August 2012 the wind direction continues to veer to a Southeasterly. Fig. 3 is a plot of aerosol backscatter coefficient for $10^{\text {th }}$ and $11^{\text {th }}$ August 2012 and demonstrates the increase of aerosol backscatter in the residual layer (RL), defined as a layer of air that originates from the convective boundary layer (CBL) of a day previously. This increase at $1 \mathrm{~km}$ during the early morning of $11^{\text {th }}$ August coincides with the prediction from the back trajectory model of air that has originated from London. A similar RL can be seen on the early morning of $10^{\text {th }}$ August, but this shows about a third of the values experienced the following night.

Ozone mixing ratio from the lidar and a nearby ground station are shown in Fig. 4. These show an ozone mixing ratio of up to $60 \mathrm{ppbv}$ at 800 metres

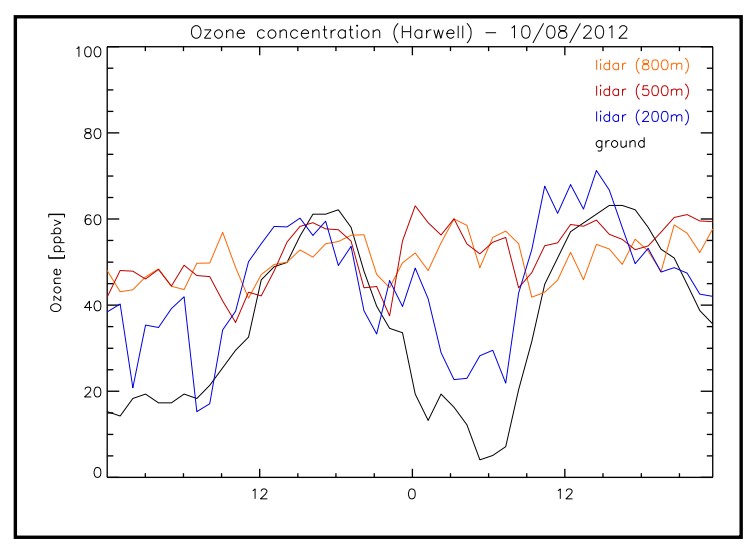

Fig. 4: Ozone mixing ratio for $10^{\text {th }}$ and $11^{\text {th }}$ August 2012. The ground-based ozone values are from the Harwell air quality monitoring site run by the UK's Department of Environment, Food and Rural Affairs (DEFRA) [6]

on the morning of $11^{\text {th }}$ August compared to $45 \mathrm{ppbv}$ on the morning of $10^{\text {th }}$ August.

Ozone mixing ratios are subject to chemical reactions with other gases and aerosol types in the atmosphere. This is visible in the ground-based data where ozone mixing ratio decreases to very low values of $3 \mathrm{ppbv}$ on the morning of $11^{\text {th }}$ August. This is pending further analysis.

\section{FUTURE WORK}

- Further work will be carried out to analyse all of the data collected, including the other incidents of easterly winds as well as the cases of other wind directions.

- The lidar data will be compared to data from a Weather Research and Forecasting (WRF) model that includes chemistry.

- Air composition data from London and Harwell will be analysed further to understand the variations in ozone with respect to chemical reactions in the atmosphere.

- A CBL height comparison will be carried out using all available lidar data during the campaign. 


\section{ACKNOWLEDGEMENT}

The authors acknowledge the Natural Environment Research Council (NERC) for the funding provided for the Clean Air for London (ClearfLo) project as well as the National Centre for Atmospheric Science's (NCAS) Atmospheric Measurement Facility (AMF) for providing the Boundary Layer Aerosol/Ozone Lidar.

\section{REFERENCES}

[1] Bohnenstengel, S. I., Belcher, S. E., Aiken, A., Allan, J. D., Allen, G., Bacak, A., Bannan, T. J., Barlow, J. F.,Beddows, D. C. S., Bloss, W. J., Booth, A. M., Chemel, C., Coceal, O., Di Marco, C. F., Dubey, M. K., Faloon, K. H., Fleming, Z. L., Furger, M., Gietl, J. K., Graves, R. R., Green, D. C., Grimmond, C. S. B., Halios, C. H.,Hamilton, J. F., Harrison, R. M., Heal, M. R., Heard, D. E., Helfter, C., Herndon, S. C., Holmes, R. E., Hopkins, J. R., Jones, A. M., Kelly, F. J., Kotthaus, S., Langford, B., Lee, J. D., Leigh, R. J., Lewis, A. C., Lidster, R. T.,Lopez-Hilfiker, F. D., McQuaid, J. B., Mohr, C., Monks, P. S., Nemitz, E., Ng, N. L., Percival, C. J., Prevot, A. S. H., Ricketts, H. M. A., Sokhi, R., Stone, D., Thornton, J. A., Tremper, A. H., Valach, A. C., Visser, S., Whalley, L. K., Williams, L. R., Xu, L., Young, D. E. and Zotter, P., 2014: Meteorology, air quality, and health in London: The ClearfLo project, Bulletin of the American Meteorological Society. doi:10.1175/BAMS-D12-00245.1

[2] Draxler, R.R. and Rolph, G.D. HYSPLIT (HYbrid Single-Particle Lagrangian Integrated Trajectory) Model access via NOAA ARL READY Website (http://www.arl.noaa.gov/HYSPLIT.php). NOAA Air Resources Laboratory, College Park, MD.

[3] Bogumil, K., J. Orphal, T. Homann, S. Voigt, P. Spietz, O. C. Fleischmann, A. Vogel, M. Hartmann, H. Kromminga, H. Bovensmann, J. Frerick \& J. P. Burrows 2003: Measurements of molecular absorption spectra with the sciamachy pre-flight model: instrument characterization and reference data for atmospheric remote- sensing in the 230-2380 nm region, Journal of Photochemistry and Photobiology a-Chemistry, 157 (2-3), 167-184
[4] Klett, J. D., 1981: Stable analytical inversion solution for processing lidar returns, Applied Optics, 20 (2), 211-220

[5] L. Komguem, priv. comm.

[6] Crown 2015 copyright Defra via ukair.defra.gov.uk, licenced under the Open Government Licence (OGL) 